\title{
SOCIO-ECONOMIC AND DEMOGRAPHIC FACTORS AFFECTING CONTRACEPTIVE USE IN WOMEN: EVIDENCE FROM THE INDONESIAN NATIONAL SOCIOECONOMIC SURVEY (SUSENAS)
}

\author{
Haerawati Idris, Iwan Stia Budi, Dian Safriantini \\ Faculty of Public Health, Sriwijaya University
}

\begin{abstract}
BACKGROUND: Family planning program plays an important role in safe motherhood. Birth spacing and correct choice of contraceptive determine maternal health and the quality of family. However, the current user of contraceptive in Indonesia among women of reproductive age is low compared with other ASEAN countries (60\%). This study aimed to determine the social, economic, and demographic factors that affect contraceptive use in Indonesia.

SUBJECTS AND METHOD: This was a cross-sectional study using secondary data derived from the national socio-economic survey (SUSENAS) in 2014. A sample of 61,970 married women was selected for this study. The dependent variable was contraceptive use. The independent variables included maternal age, number of living children, family income, maternal schooling, maternal employment status, rural urban residence, and region of residence. Multiple logistic regression analyses were used to estimate the effects of socio-economic and demographic variables on contraceptive use.

RESULTS: Only 39\% of married women in Indonesia used contraceptive. The most popular contraceptive method used was injection (55\%). Factors affecting contraceptive use were maternal age over 30 years $(\mathrm{OR}=1.11 ; 95 \% \mathrm{CI} 1.05$ to $1.17 ; \mathrm{p}<0.001)$, number of living children $>2$ (OR $=1.5 ; 95 \% \mathrm{CI} 1.48$ to $1.68 ; \mathrm{p}<0.001)$, secondary school $(\mathrm{OR}=0.92 ; 95 \% \mathrm{CI}$ 0.89 to $0.96 ; \mathrm{p}<0.001)$, family income quintile 5 ( $\mathrm{OR}=0.89 ; 95 \% \mathrm{CI} 0.84$ to $0.94 ; \mathrm{p}<0.001)$, work outside $(\mathrm{OR}=0.88 ; 95 \% \mathrm{CI} 0.85$ to $0.91 ; \mathrm{p}<0.001)$, living in urban area (OR $=0.86 ; 95 \% \mathrm{CI} 0.83$ to $0.89 ; \mathrm{p}<0.001)$, residing in Java/Bali (OR = 1.41; 95\%CI 1.35 to $1.47 ; \mathrm{p}<0.001$ ).

CONCLUSION: Maternal age over 30 years, number of children $>2$, and residing in Java/Bali, increase the likelihood of contraceptive use. Secondary school, family income quintile 5, work outside, and living in urban area, decrease the likelihood of contraceptive use. Family planning policy, information, education, and communication programs should consider these determinants of contraceptive use.
\end{abstract}

Keywords: contraceptive use, women, socio-economic demographic factors, Susenas 